\title{
PENILAIAN RISIKO IKLIM PADA SISTEM PERTANIAN \\ EKOSISTEM LAHAN RAWA PASANG SURUT \\ (Studi kasus di Delta Telang I, Delta Telang II dan Delta Air Saleh, Banyuasin, Sumatera Selatan)
}

(Climate Risk Assesment on Agricultural System in Swamp Areas (case Study in Delta

Telang I, Delta Telang II and Delta Air Saleh, Banyuasin, South Sumatera))

\section{Suciantini ${ }^{1}$, Impron ${ }^{2}$ dan Rizaldi Boer ${ }^{2}$}

1) Balai Penelitian Agroklimat dan Hidrologi, Cimanggu- Bogor

2) Institut Pertanian Bogor

E-mail:suciantini@yahoo.com

\begin{abstract}
The characteristics of swampland areas are different from agricultural land of Java, mainly in water availability. In swampland ecosystems there are unique environmental conditions. To assess risks of climate, mainly in climate change, we must assess about capacity and adaptation strategy. From treasure of related institution and interview with farmers, its had been known about climate impact on farming systems application, rainfall pattern and water availability. This paper aims to assess risks of climate on farming systems, application of adaptation strategy to reduce risks of climate and probability to provide of planting pattern alternative in the future in swampland areas (tidal marsh) in Delta Telang I, Delta Telang II and Delta Air Saleh, Banyuasin, South Sumatera.
\end{abstract}

Keywords: farming system, risks of climate, South Sumatera, swampland ecosystem, tidal marsh

\section{Pendahuluan}

Interaksi antara cuaca atau iklim dan pertanian sangat kompleks, karena variasinya pada respon fisik, lingkungan dan biologi secara ruang dan waktu. Ekosistem lahan rawa mempunyai kondisi lingkungan yang unik, yang memungkinkan mengalami respon yang berbeda terhadap pengaruh kejadian iklim, terutama iklim ekstrim dan kejadian yang menimbulkan bencana akibat iklim.

Menurut Subagyo (2006a), lahan rawa sebenarnya merupakan lahan yang menempati posisi peralihan di antara sistem daratan dan sistem perairan (sungai, danau, atau laut), yaitu antara daratan dan laut, atau di daratan sendiri, antara wilayah lahan kering (uplands) dan sungai/danau. Karena menempati posisi peralihan antara system perairan dan daratan, maka lahan ini sepanjang tahun, atau dalam waktu yang panjang dalam setahun (beberapa bulan) tergenang dangkal, selalu jenuh air, atau mempunyai air tanah dangkal.

\footnotetext{
Penyerahan naskah : 29 Juli 2008

Diterima Untuk diterbitkan : 26 Agustus 2008
} 
Selanjutnya Subagyo (2006b) berpendapat bahwa Delta Telang termasuk ke dalam wilayah pasang surut air tawar, yaitu wilayah rawa dimana dimana pengaruh langsung air laut/salin sudah tidak ada lagi, tetapi energi pasang surut masih terasa berupa naik dan turunnya air (tawar) sungai mengikuti siklus gerakan air pasang surut.

Kondisi lingkungan yang unik, memungkinkan pola pertanian lahan rawa juga bersifat khas. Terdapatnya kandungan pirit di lahan rawa juga merupakan salah satu kendala untuk pertanian. Kandungan pirit di tanah rawa pasang surut umumnya rendah, yakni hanya sekitar $0-5 \%$, namun walaupun kadarnya rendah, temyata di kemudian hari menjadi permasalahan utama yang berat, atau sangat sulit diatasi, apabila tanah rawa dibuka untuk pertanian. Masalahnya dimulai pada saat rawa direklamasi, yaitu dengan penggalian saluran-saluran drainase besar, seperti saluran primer, sekunder, dan tersier, dengan tujuan untuk mengeringkan wilayah agar tanah rawa yang semula basah atau tergenang menjadi tanah yang relatif lebih kering yang siap digunakan sebagai lahan pertanian (Subagyo, 2006b). Mengingat pembuatan saluran memungkinkan pirit muncul pada permukaan yang lebih dangkal dan mengalami oksidasi yang memungkinkan terganggunya kondisi lingkungan perakaran tanaman. Dalam pelaksanaan pertanian, kondisi lingkungan yang bersifat tergenang membutuhkan pengelolaan air yang berbeda dari lahan sawah biasa. Selain itu, perlu diperhatikan juga pemilihan jenis varietas supaya dapat memberikan hasil optimal. Menurut Jumberi dan Alihamsyah (2006), karena kondisi lahan rawa yang spesifik, menyebabkan hanya beberapa jenis komoditas dan varietas tertentu saja yang dapat tumbuh dan memberikan hasil baik. Dari hasil pengujian dan pengalaman pengembangan di lapangan, Badan Litbang Pertanian telah mengidentifikasi berbagai jenis komoditas pertanian dan varietas tanaman yang dapat tumbuh dan berkembang dengan baik di lahan pasang surut, baik berupa varietas unggul lokal maupun varietas unggul nasional. Dalam kaitannya dengan penilaian risiko iklim di lahan rawa adalah menelaah suatu keadaan yang menyebabkan kegagalan atau kerusakan pada pertanian di lahan rawa tersebut. Risiko (risk) berhubungan dengan ketidakpastian, yang merujuk kepada keadaan yang peluang kejadiannya tidak dapat diduga (Boer, 2002). Boer dan Subbiah (2005) menyatakan bahwa berdasarkan data historis dampak kejadian iklim, diketahui bahwa luas total kerusakan dan kehilangan akibat kejadian iklim ekstrim, terutama banjir dan kekeringan, cenderung meningkat dari waktu ke waktu. Karena ekosistem lahan rawa memiliki karakter yang berbeda, sehingga ingin diketahui bagaimana kondisinya ketika iklim ekstrim terjadi dan seberapa besar peluang terjadinya bencana akibat iklim ekstrim dapat menyebabkan kerugian pada sistem pertanian lahan rawa, terutama rawa pasang surut dan bagaimana respon yang dilakukan? Mengingat bagaimana kondisi lahan rawa akibat keragaman dan perubahan iklim belum banyak dikaji.

Tulisan ini bertujuan untuk melakukan penilaian terhadap risiko iklim yang terjadi pada pertanian ekosistem lahan rawa, dan aplikasi strategi adaptasi yang harus dilakukan untuk 
mengurangi risiko iklim serta rekomendasi alternatif pola tanam yang dapat diaplikasikan pada masa yang akan datang di Delta Telang I, Delta Telang II dan Delta Air Saleh, Banyuasin, Sumatera Selatan.

\section{Bahan dan Metode}

Kegiatan penelitian ini ditujukan untuk melakukan penilaian risiko iklim pada sistem pertanian lahan rawa pasang surut di Delta Telang I, Delta Telang II dan Delta Air Saleh, Banyuasin, Sumatera Selatan (Gambar 1). Penilaian risiko iklim didasarkan kepada kejadian iklim ekstrim yang menyebabkan terjadinya banjir, kekeringan maupun pasang besar. Penilaian diperoleh dari data primer yang dilakukan berdasarkan interview dengan responden yang pada umumnya petani. Sebagai acuan dalam wawancara digunakan quisioner. Responden diperoleh dari 21 Desa pada ketiga Delta tersebut. Pemilihan responden juga dilakukan berdasarkan perbedaan tipologi lahan. Pelaksanaan survai dilakukan pada bulan Agustus 2009. Dilakukan juga analisa data iklim, terutama data curah hujan, untuk mengetahui perubahan pola hujan.

Bahan yang dilakukan untuk penilaian selain berdasarkan hasil wawancara dengan responden, juga berdasarkan data penunjang yang diperoleh dari Dinas Pertanian Banyuasin, menyangkut luas areal tanam, luas panen, awal tanam dan lain-lain. Pengambilan data juga dilakukan pada institusi terkait lainnya.

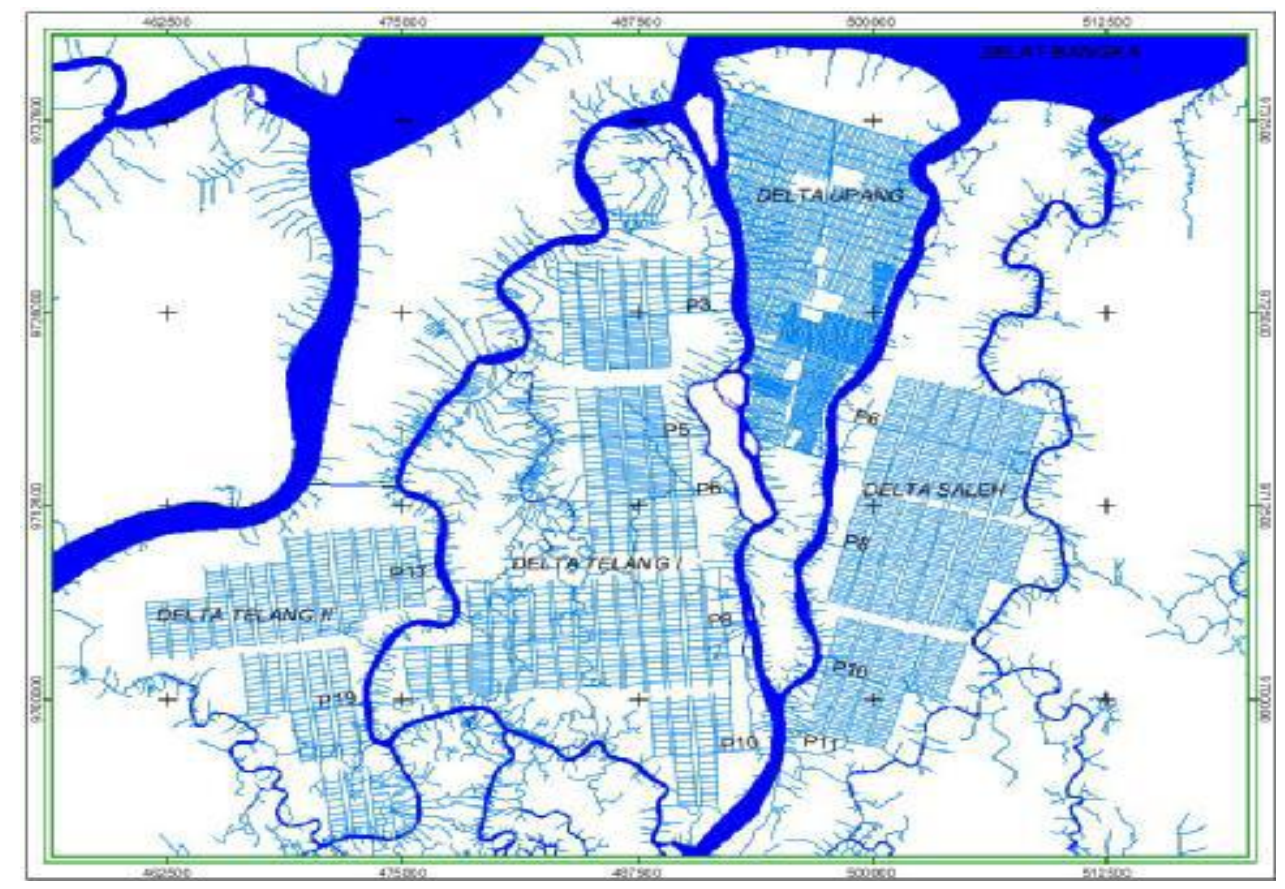

Gambar 1. Jaringan tata air rawa Delta Telang I, Telang II dan Air Saleh (Boer dan Tim, 2009) 


\section{Hasil dan Pembahasan}

\section{Ketersediaan air di lahan rawa}

Sumberdaya air pertanaman padi pada ketiga delta tersebut mengandalkan hujan sebagai input utama, di samping air dari jaringan terutama ketika pasang. Berdasarkan ketersediaan airnya, lahan usaha responden dapat digolongkan ke dalam empat tipe luapan, yaitu tipe pertama (A) merupakan tipe lahan yang selalu terluapi oleh air pasang, baik pasang besar maupun kecil, tipe yang kedua (B), lahan selalu terluapi oleh air pasang besar saja, tetapi tidak terluapi oleh pasang kecil atau pasang harian, tipe ketiga (C) lahan tidak terluapi oleh air pasang besar, tetapi air tanah berada $<50 \mathrm{~cm}$ dari permukaan tanah dan tipe keempat (D) lahan tidak terluapi oleh air pasang dan air tanah berada pada kedalaman $>50 \mathrm{~cm}$ dari permukaan tanah. Untuk tipe pertama dan kedua, kondisi ketersediaan air terutama untuk musim tanam I, tidak menjadi masalah. Sedangkan untuk tipe ketiga dan keempat, ketersediaan air menjadi faktor pembatas, terutama untuk tipe keempat yang adakalanya, untuk lokasi lahan yang tinggi, air tidak masuk ke lahan. Sehingga hanya mengandalkan air hujan sebagai sumber pengairannya. Akibatnya apabila awal musim hujan terlambat, bisa terjadi kekeringan di lahan. Gambaran pendapat responden mengenai sumber air untuk pertanian disajikan pada Gambar 2.

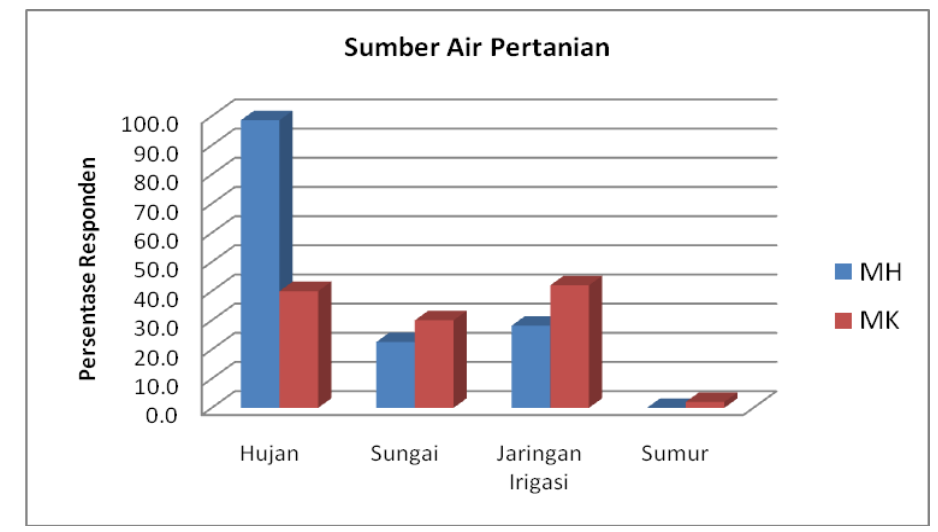

Gambar 2. Sumber air untuk pertanian pada musim hujan dan musim kemarau

\section{Pola pertanian di lahan rawa}

Pola tanam di ketiga delta, umumnya sama yaitu padi-bera (Gambar 3). Hanya sebagian petani di Telang I yang memanfaatkan air di rawa hingga pertanaman MT III dengan pola tanam : padi-padi atau padi-padi-palawija (Gambar 4). Data dari Dinas Pertanian dan Peternakan Banyuasin tahun 2009, menyatakan bahwa capaian luas tanam padi pada MT 2008/2009 dan MT 2009 di lokasi pasang surut, seluas 157.562 ha. Sedangkan berdasarkan perkiraan realisasi luas tanam akhir tanaman padi pada MT 2008-2009 dan MT 2009 per kecamatan, diperoleh data 
sebagai berikut; Muara Telang (yang melingkupi Delta Telang I) seluas 30.096 ha, Tanjung Lago (yang melingkupi Delta Telang II) seluas 11.359 ha dan Air Saleh (Delta Air Saleh) seluas 16.153 ha. Berdasarkan diskusi dengan petani diketahui bahwa pola pertanaman petani hanya didasarkan pada keserempakan dalam memulai tanam, tanpa memperhitungkan bagaimana musim yang terjadi. Menurut petani terutama yang mengalami pasang surut di lahan, air cukup tersedia untuk penanaman hingga MT3. Tidak demikian halnya dengan petani yang lahannya tidak dimasuki air pasang, musim tanam harus benar-benar diperhitungkan, karena air tidak tersedia di lahan, sehingga pertanaman yang tidak tepat waktu dapat menyebabkan kekeringan. Pada tipe ini, terjadinya perubahan iklim akan secara tegas dirasakan, dibanding petani yang lahannya selalu digenangi pasang. Permasalahan lain adalah ketika musim kemarau panjang, air menjadi lebih asin, sehingga pertanaman dengan kondisi salinitas tinggi ini dapat menyebabkan penurunan produksi. Hal ini dikuatkan oleh pendapat Subagyo (2006a) bahwa pada wilayah pasang surut, saat musim kemarau, pada saat volume air sungai relatif tetap atau malahan berkurang, pengaruh air asin/salin dapat merambat sepanjang sungai sampai jauh ke pedalaman. Pada bulan-bulan terkering, Juli-September, pengaruh air asin/salin di sungai dapat mencapai jarak sejauh 40-90 km dari muara sungai. Dalam kaitannya dengan produksi, menurut Marschner (1988) dalam Umboh (1996), laju fotosintesis bersih menjadi lebih rendah pada tingkat salinitas tinggi dan hal ini diakibatkan oleh turunnya kadar klorofil per unit luas daun. Rendahnya laju fotosintesis ini mengakibatkan terjadinya penurunan produksi tanaman.

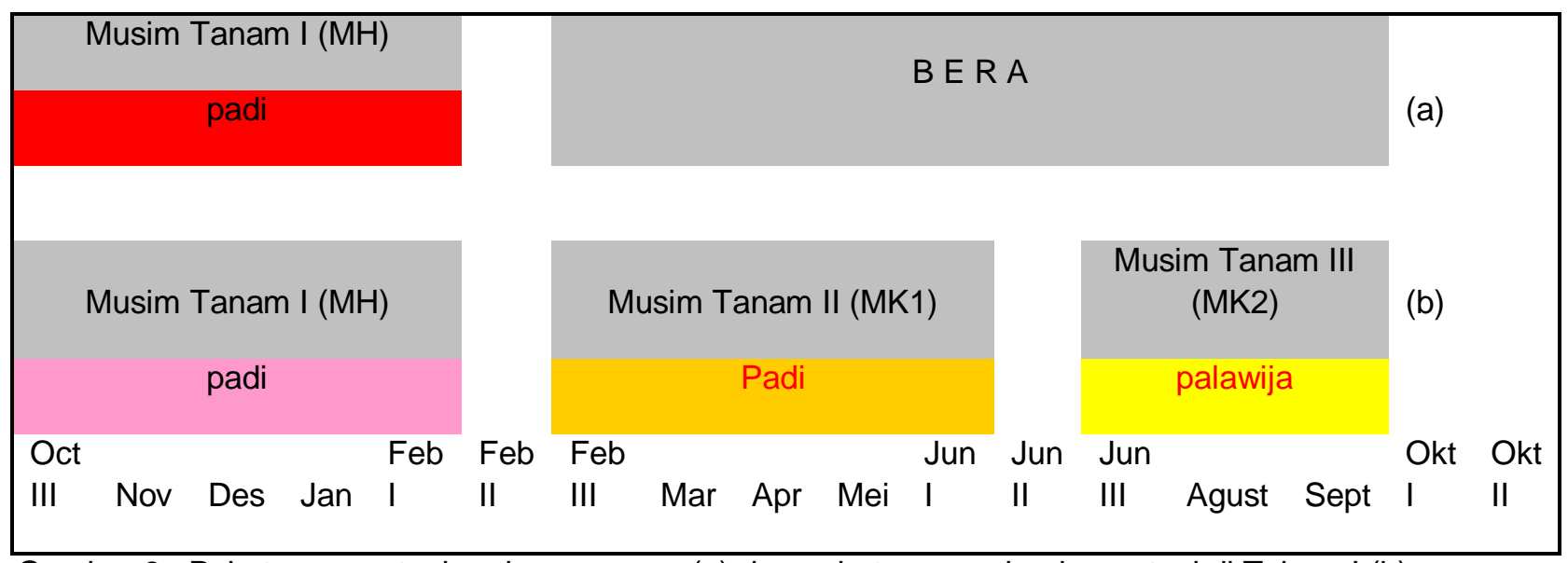

Gambar 3. Pola tanam petani pada umumnya (a) dan pola tanam sebagian petani di Telang I (b) 


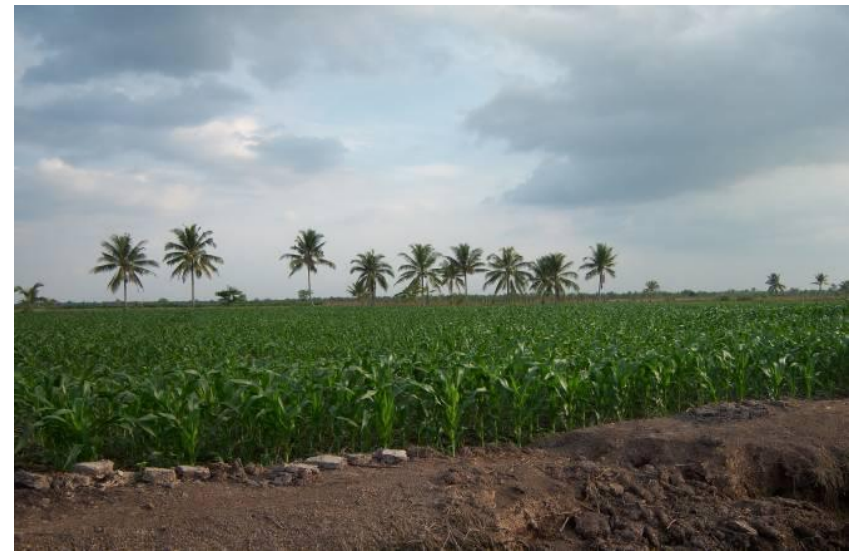

Gambar 4. Pertanaman jagung pada MT3 di Desa Telang Karya (Delta Telang I)

\section{Risiko bencana iklim di lahan rawa}

Berdasarkan diskusi dengan petani di lahan rawa mengenai kejadian iklim ekstrim seperti banjir, kekeringan, angin kencang, instrusi air laut maupun pasang tinggi, diperoleh hasil bahwa pada umumnya petani tidak terlalu merasa mengalami kejadian iklim ekstrim tersebut. Namun demikian, sebagian petani tetap menganggap bahwa kejadian iklim ekstrim, seperti banjir dan kekeringan terjadi. Hal yang membedakan pendapat petani tersebut terutama adalah perbedaan penggenangan pada lahan yang membedakan kondisi lahan petani, selain dari posisi lahan sendiri. Pada lahan-lahan yang rendah, kemungkinan air pasang menggenangi lahan. Pada kondisi lahan seperti ini, pertanaman dapat dilakukan hampir sepanjang tahun, karena air tersedia, seperti yang terjadi di Desa Telang Karya (Delta Telang I). Di Desa Telang Karya, TAM (tata air mikro) berfungsi dengan baik, demikian pula dengan pintu airnya, sehingga lahan petani mendapat cukup air untuk pertanamannya. Sedangkan apabila terjadi hujan besar dan pasang, air yang masuk ke lahan, akan surut kembali diantaranya lewat gorong-gorong yang tersedia pada setiap lahan petani menuju saluran tersier.

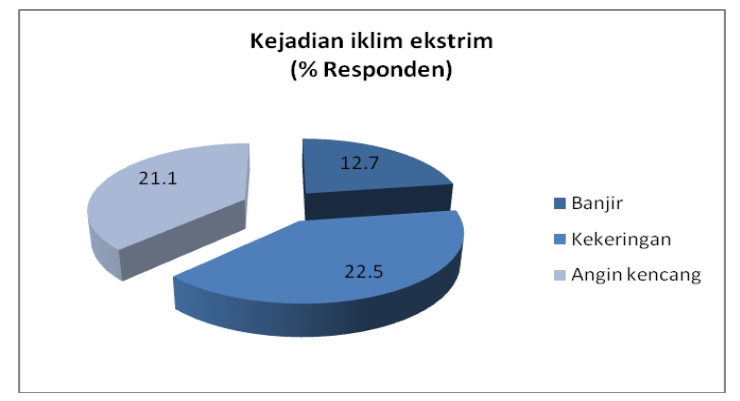

Gambar 5. Kejadian iklim ekstrim yang terjadi pada ketiga delta berdasarkan pengamatan responden 
Menurut petani yang berpendapat mengalami kejadian iklim ekstrim (Gambar 5), kejadian ini biasanya terjadi berupa banjir, kekeringan dan angin kencang. Kejadian ini cukup merugikan pertanaman petani sehingga berdasarkan data dari sebagian kecil petani, diperoleh bahwa pada kejadian banjir, kekeringan dan angin kencang terdapat kerugian petani, karena terjadi penurunan produksi akibat tanaman kurang air (hal ini terjadi pada lokasi lahan yang tinggi) yang mereka sebut sebagai tadah hujannya wilayah rawa, atau pertanaman roboh karena angin, yang menyebabkan rusaknya tanaman dan kehilangan sebagian produksinya. Berdasarkan Gambar 6, diperoleh bahwa akibat iklim esktrim yang terjadi, ketiga delta mengalami kerugian antara Rp. 2.500.000,00 hingga Rp. 3.776.000,00 (data tidak berasal dari keseluruhan responden/hanya dari responden yang mengalami kerugian).

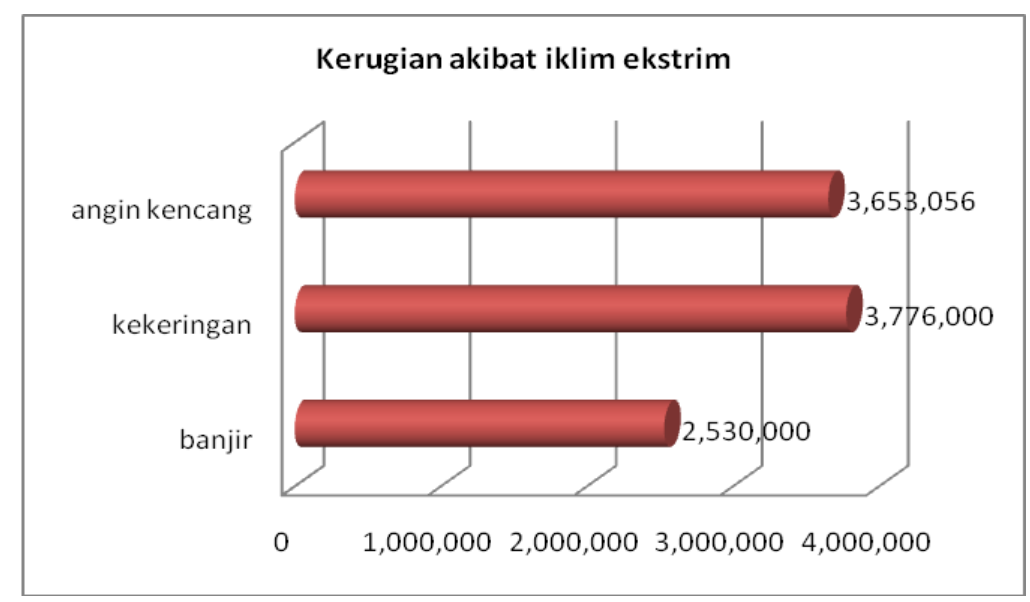

Gambar 6. Rata-rata kerugian akibat iklim ekstrim yang terjadi pada tiga delta berdasarkan perkiraan responden

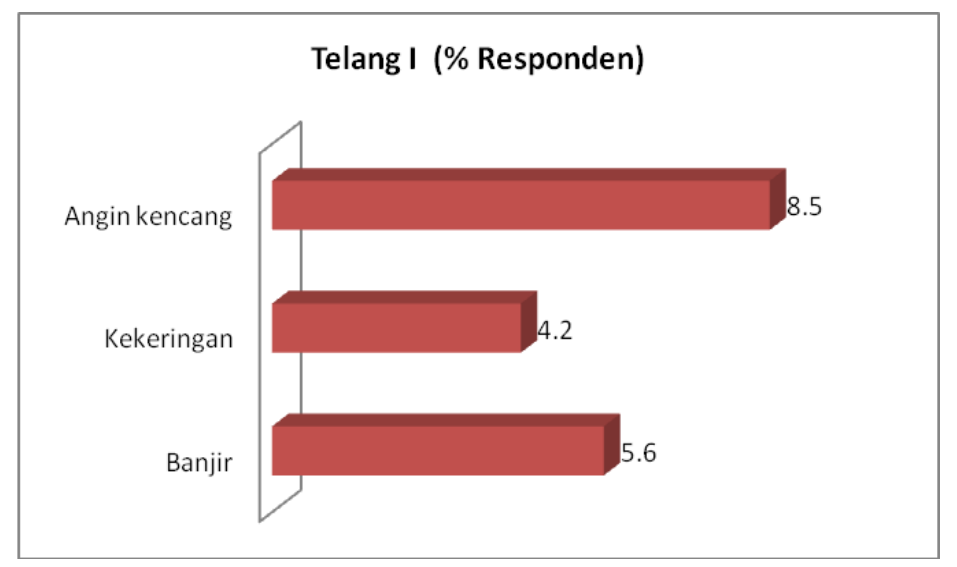

Gambar 7. Kejadian iklim ekstrim yang terjadi di Delta Telang I berdasarkan jumlah responden

Pada sebagian petani, keadaan banjir adalah sama dengan genangan, yang menurutnya dalam beberapa jam akan surut dan hal itu tidak akan menyebabkan kerugian, kecuali terganggunya aktivitas, karena infrastuktur yang kurang mendukung. Infrastruktur jalan dan 
jembatan yang sangat penting, pada sebagian lokasi akan terganggu, karena permukaan jalan merupakan tanah liat, yang apabila terjadi hujan, cukup menghambat aktivitas.

Gambar 7 memperlihatkan kejadian iklim ekstrim yang terjadi di Telang I. Dari gambar terlihat bahwa untuk Delta Telang I, menurut responden bencana yang mungkin paling besar adalah angin kencang dan banjir, sedangkan kekeringan berada pada urutan terakhir. Hal itu dapat dimaklumi, karena untuk Telang I umumnya terluapi genangan, sehingga kemungkinan terjadi kekeringan lebih kecil.

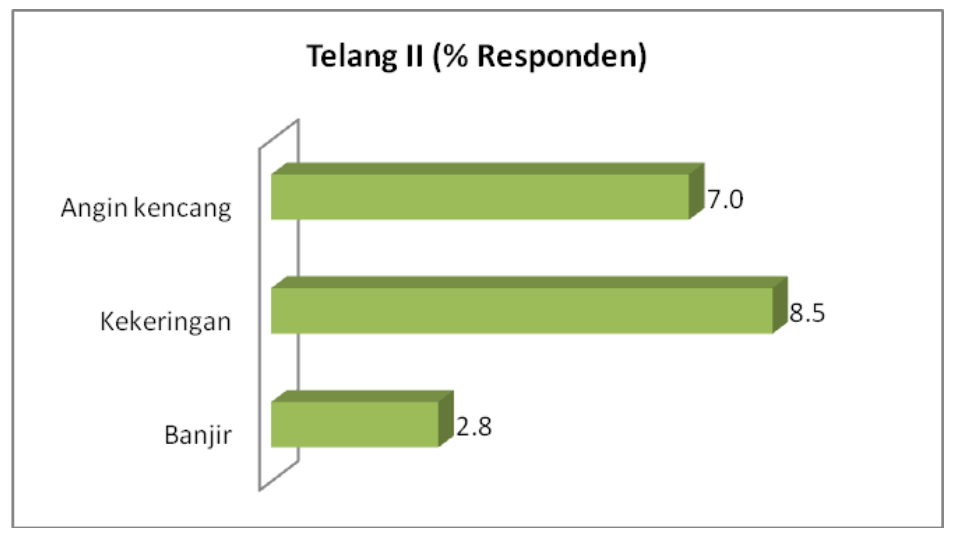

Gambar 8. Kejadian iklim ekstrim yang terjadi di Delta Telang II berdasarkan jumlah responden

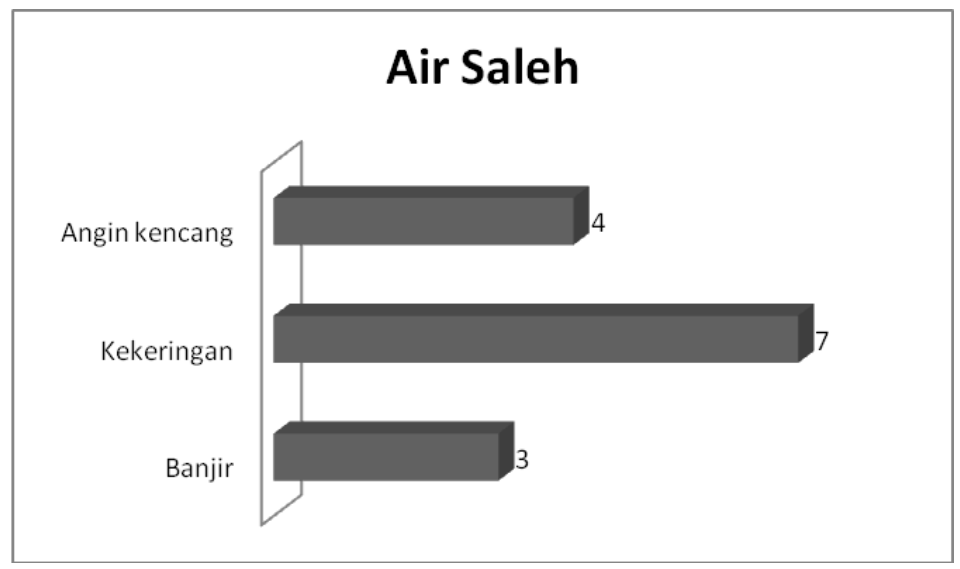

Gambar 9. Kejadian iklim ekstrim yang terjadi di Delta Air Saleh berdasarkan jumlah responden

Berdasarkan hasil diskusi dengan responden diketahui pula bahwa di Telang II bencana yang mendominasi adalah kekeringan. Meskipun posisi Telang II sebetulnya yang paling dekat dengan sungai, tetapi kondisi lahan lebih tinggi menyebabkan tidak seluruh lahan tergenang pada saat pasang (Gambar 8). Sementara itu, wilayah yang paling mungkin juga mengalami kekeringan adalah Air Saleh (Gambar 9). Diketahui bahwa terdapat lahan-lahan petani di wilayah ini yang tidak terluapi air genangan sepanjang tahun, karena posisi lahan yang tinggi. Sumber 
pengairan mengandalkan pada air hujan. Hampir serupa dengan lahan tadah hujan pada sawah biasa.

\section{Musim hujan}

Musim hujan berlangsung bulan Oktober-Maret (Gambar 10-11). Enam puluh delapan persen responden menyatakan bahwa awal musim hujan berlangsung bulan Oktober, yang sekaligus juga dijadikan waktu untuk memulai bertanam padi secara serempak. Sedangkan sebagian responden menyatakan awal MH pada bulan September, yang digunakan oleh mereka sebagai persiapan untuk tabur benih di lahan, secara tabur kering. Tabur kering adalah menabur benih pada tanah yang sudah ditraktor dan digaru, kemudian benih ditutup. Hal ini dilakukan sambil menunggu hujan. Kalau hujan turun, 15 hari sesudah berkecambah baru dipupuk dengan urea sekitar 1 kuintal/ha. Sebagian responden menyatakan bahwa awal musim hujan juga dapat mundur hingga November.

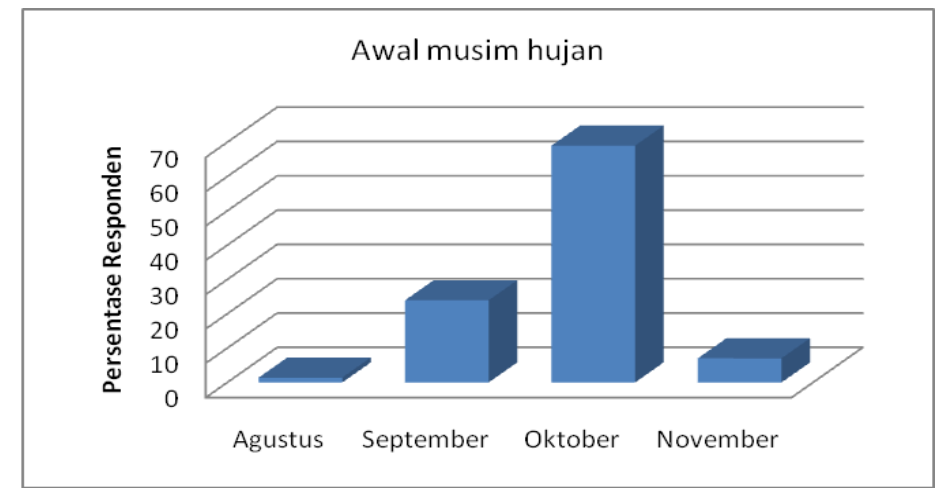

Gambar 10. Awal Musim Hujan menurut responden

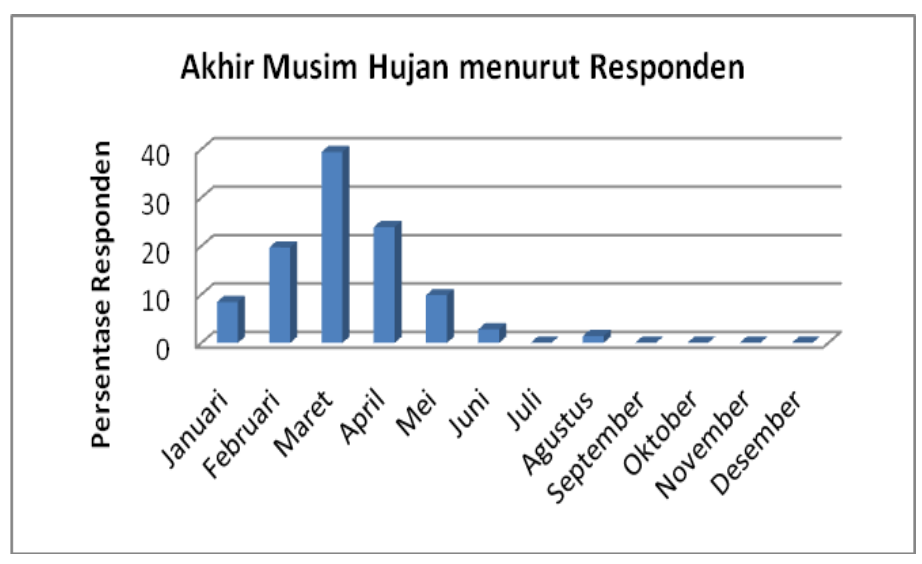

Gambar 11. Akhir Musim Hujan menurut responden 


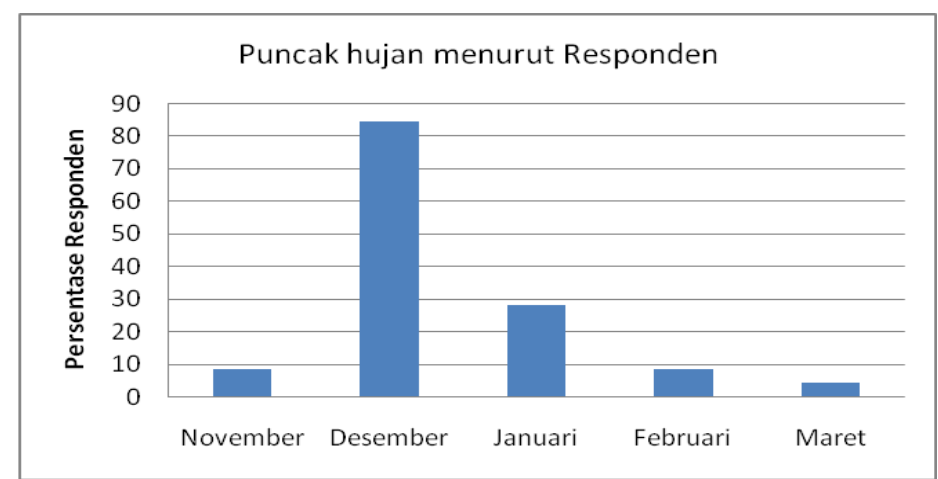

Gambar 12. Puncak hujan menurut responden

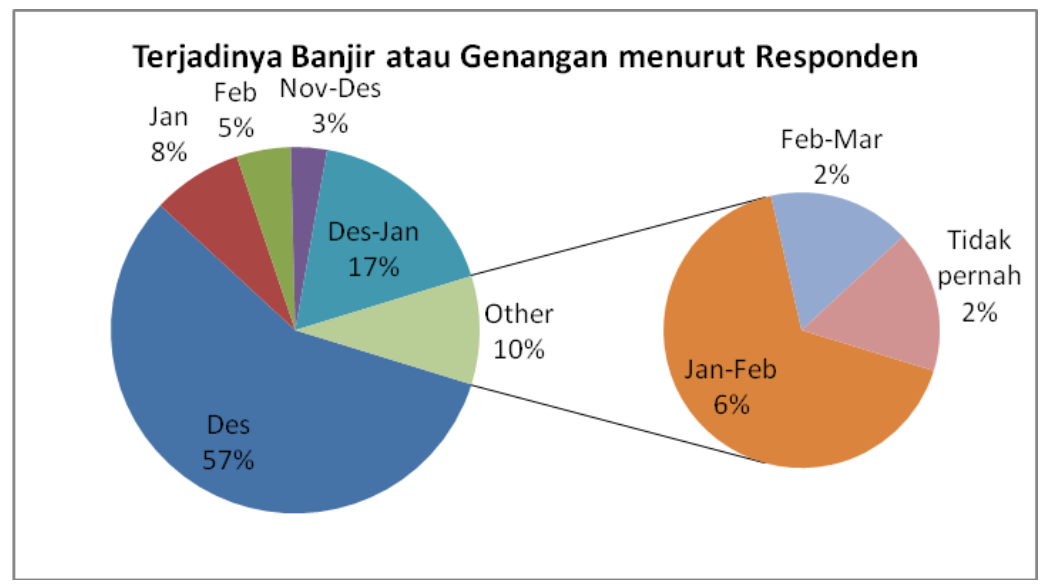

Gambar 13. Bulan-bulan terjadinya banjir dan genangan menurut responden

Jika untuk awal musim hujan pendapat responden hampir mendekati seragam, lain halnya untuk akhir musim hujan. Jawaban responden sangatlah bervariasi, mulai dari Januari hingga Agustus. Namun demikian, pada umumnya responden menjawab bulan Maret sebagai akhir musim hujan (Gambar 11). Demikian pula ketika ditanyakan mengenai puncak hujan, jawaban yang diperoleh sangat bervariasi (Gambar 12). Namun Bulan Desember disebutkan sebagai puncak musim hujan menurut sebagian besar responden.

Banjir dan genangan terjadi pada saat curah hujan tinggi, yang biasa juga diikuti dengan pasang besar. Sesuai penuturan responden sebelumnya bahwa puncak musim hujan pada bulan Desember, maka menurut sebagian besar responden (Gambar 13) bulan Desember dapat terjadi banjir dan genangan, yang dipicu dengan jumlah hujan yang banyak dan tingginya pasang.

Tinggi genangan bervariasi dari $<30 \mathrm{~cm}$ hingga $>1 \mathrm{~m}$. Pada saat pasang tinggi ataupun curah hujan tinggi, kondisi genangan di pekarangan $<30 \mathrm{~cm}$, sedangkan di lahan $>0.5 \mathrm{~m}$. Mengenai lama genangan, umumnya menurut petani, genangan akan surut secara cepat di Telang II dan Air Saleh. Lama genangan umumnya beberapa jam (kurang dari satu hari), meskipun ada juga yang menjawab kurang dari satu jam atau lebih $>1$ hari. Lahan lebih lama tergenang, biasanya karena posisi lahan berada di bawah. 


\section{Kekeringan}

Kurangnya air pada musim kemarau, sangat dirasakan oleh petani yang lahannya tidak terluapi genangan. Oleh karena itu diperlukan beberapa aplikasi praktis untuk memenuhi kebutuhan air tanaman, apabila petani menanami lahannya pada musim tanam kedua. Namun pada umumnya petani tidak melakukan penanaman mulai musim tanam ke-2. Selain berkurangnya/tidak tersedianya curah hujan, alasan kemungkinan meningkatnya salinitas merupakan sebab mengapa petani enggan menanam pada musim tanam berikutnya. Petani yang menanam pada musim kedua dan bahkan ketiga dengan bertanam palawija, hanya ditemui di Telang I. Pendapat mengenai tingkat kejadian kekeringan terparah disajikan pada Gambar 14.

Di lahan rawa pasang surut ternyata memiliki rekaman kekeringan terparah yang hampir sama dengan lahan sawah irigasi biasa. Kekeringan yang dirasakan pada tahun-tahun terjadinya El-Nino, dirasakan pula di sini, berupa kekeringan yang panjang dengan menurunnya produksi padi dan pada sebagian lahan terjadi kebakaran. Menurut responden, kekeringan terparah terjadi pada tahun 1982, 1994, dan 1997 (Gambar 14).

Pendapat tersebut sejalan dengan kondisi kekeringan di lahan sawah seperti yang terjadi di Indramayu. Boer and Team (2003) menyatakan bahwa apabila kerugian tersebut diperkirakan maka di Kabupaten Indramayu pada tahun El-Nino 1991, 1994 dan 1997, perkiraan kerugian ekonomi akibat kegagalan panen pada tahun El-Nino dapat mencapai 371 milyar sedangkan kehilangan investasi yang dialami petani dapat mencapai 228 milyar. Dengan demikian, sesungguhnya di lahan rawa juga harus dilakukan pengelolaan risiko iklim untuk mengurangi kerugian yang mungkin terjadi akibat kerusakan yang ditimbulkan bencana iklim.

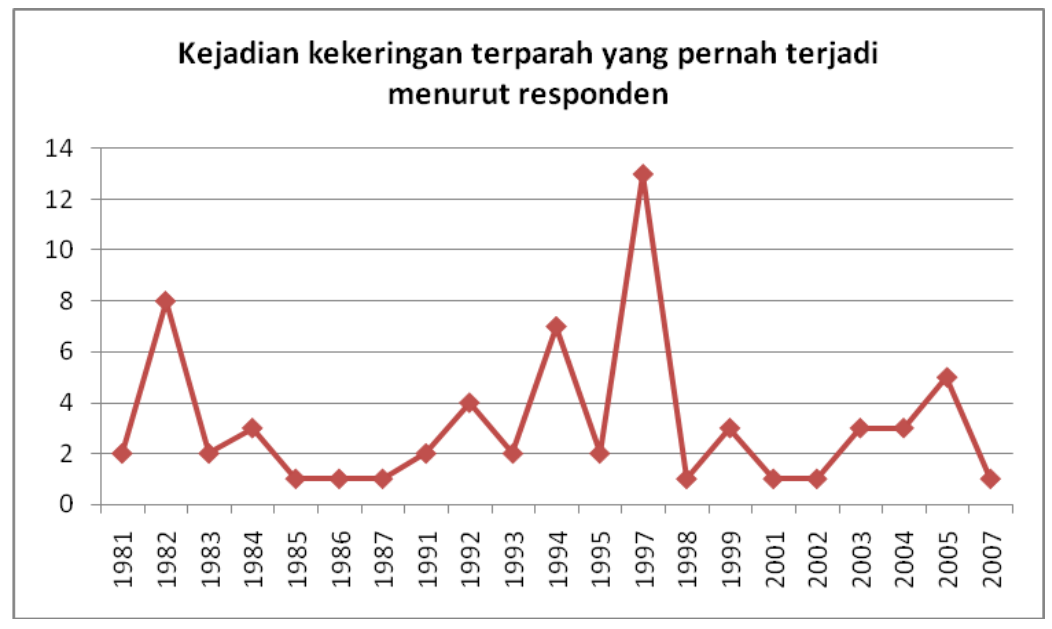

Gambar 14. Tahun-tahun terjadinya kekeringan terparah menurut responden 
Penilaian Resiko Iklim

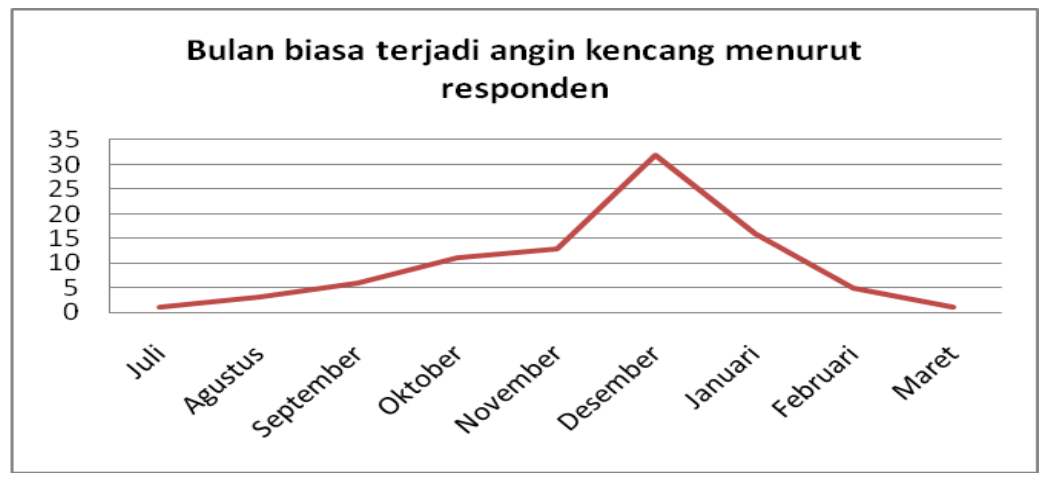

Gambar 15. Bulan terjadinya angin kencang menurut responden

Angin kencang biasanya terjadi pada saat musim hujan. Gambar 15 memperlihatkan terjadinya angin kencang bersamaan dengan saat puncak musim hujan yaitu Bulan Desember. Menurut responden, di wilayah ini angin kencang biasa terjadi pada bulan-bulan Juli hingga Maret, dengan pendapat terbanyak pada bulan Desember. Menurut responden, tahun-tahun terjadinya angin kencang juga terjadi pada tahun 1994 dan 1997. Kejadian angin kencang pada tahun-tahun tersebut dapat merupakan pemicu meluasnya kebakaran lahan di wilayah ini.

Kekuatan angin pada skala yang besar secara visual dapat terlihat dari tumbangnya pohon atau diterbangkannya atap. Namun demikian, dapat juga terjadi angin yang cukup kuat, namun tidak sampai menumbangkan pohon ataupun menerbangkan atap.

\section{Pemilihan pola tanam}

Pemilihan pola tanam dan komoditas pertanian berkaitan erat dengan pola penataan lahan dan ketersediaan air, dimana sumber air di lahan pasang surut berasal dari air pasang dan air hujan atau hanya air hujan saja tergantung kepada tipe luapan airnya. Bervariasinya jangkauan air pasang di lahan pasang surut mengakibatkan adanya perbedaan suplai air ke petakan lahan untuk menunjang keperluan tanaman (Jumberi dan Alihamsyah, 2006).

Pola tanam untuk petani di lahan pasang surut yang pengaturan tata airnya baik pada tipe luapan A, dapat ditingkatkan hingga ke MT3. Penanaman pada MT3 dapat berupa padi atau palawija. Disarankan untuk menggunakan padi dengan varietas genjah. Keserampakan petani untuk melakukan penanaman pada MT3 dapat mengurangi serangan hama, terutama hama tikus. Hal yang penting yang harus diperhatikan adalah pintu air dari saluran tersier ke lahan atau juga pintu-pintu pengatur tingginya permukaan air, sehingga ketika pasang tinggi, air masuk ke lahan, dan akan kembali ke saluran ketika surut melalui gorong-gorong, seperti yang terjadi di Desa Telang Karya. Menurut Suprihatno et al (1999) dalam Jumberi dan Alihamsyah (2006) Kendala pada lahan ini adalah tingginya genangan air pada musim hujan sehingga diperlukan varietas lebih tinggi dari genangan maksimum. Sedangkan pada musim kemarau panjang karena seringnya 
mengalami intrusi air laut, maka diperlukan varietas yang tahan salinitas. Untuk mengurangi risiko kerugian terutama pada kondisi kemarau panjang, penanaman dapat juga dilakukan hanya dua kali, padi-padi. Pada tipe luapan B, pola tanam yang dapat dikembangkan, yaitu padi-padi atau padi-palawija, dengan catatan pabila dilakukan penanaman palawija perlu memperhatikan tata air tertentu pada petakan lahan agar terhindar dari genangan air. Penanaman padi pada musim kemarau, tergantung pada kemampuan air pasang masuk ke petakan lahan. Pada tipe luapan C, sumber air utama berasal dari curah hujan seperti halnya sawah tadah hujan, maka pola tanam yang memungkinkan padi-palawija, dengan catatan saluran drainase harus berjalan dengan baik. Sedangkan tipe $D$ lebih bersifat seperti lahan kering dengan

sumber air utama dari hujan dengan pola tanam yang sesuai adalah padi-palawija/sayuran atau palawija-palawija/sayuran.

\section{KESIMPULAN}

Bencana iklim terutama banjir dan kekeringan juga rawan terjadi pada sebagian lahan rawa pasang surut, meskipun sebagian responden menyatakan tidak menerima dampak yang besar dari kejadian bencana tersebut. Di lahan rawa pasang surut ternyata memiliki rekaman kekeringan terparah yang hampir sama dengan lahan sawah irigasi biasa. Pada tahun-tahun terjadinya ElNino, dirasakan pula di sini, berupa kekeringan yang panjang dengan menurunnya produksi padi dan pada sebagian lahan terjadi kebakaran. Menurut responden, kekeringan terparah terjadi pada tahun 1982, 1994, dan 1997. Dengan demikian, sesungguhnya di lahan rawa juga harus dilakukan pengelolaan risiko iklim untuk mengurangi kerugian yang mungkin terjadi akibat kerusakan yang ditimbulkan bencana iklim.

\section{UCAPAN TERIMA KASIH}

Tulisan ini menggunakan sebagian data hasil survai kerjasama CCROM dengan Departemen PU Direktorat Rawa. Terima kasih disampaikan kepada semua pihak yang telah bekerjasama.

\section{PUSTAKA}

Boer R. 2002. Analisis Risiko Iklim untuk Produksi Pertanian. Paper disajikan dalam Pelatihan Dosen PT Se Sumatera-Kalimantan dalam Bidang Pemodelan dan Simulasi Pertanian dan Lingkungan, Bogor 1-13 Juli 2002.

Boer R and Team. 2003. Climate Forecast Information Application : Case Study at Indramayu District. Report submitted to Asian Disaster Preparedness Centre, Bangkok, Thailand.

Boer R, Subbiah AR. 2005. Agricultural droughts in Indonesia. In V.K. Boken, A.P. Cracknell, and R.L. Heathcote. Monitoring and Predicting Agriculture Drought. Oxford University Press, p:330-344. 
Boer $\mathrm{R}$ dan Tim. 2009. Pengaruh Perubahan Iklim terhadap Daerah Rawa yang Sudah Dikembangkan (Laporan Antara) Kerjasama CCROM-Departemen PU Direktorat Rawa.

Dinas Pertanian dan Peternakan Banyuasin. 2009. Bahan Evaluasi dalam rangka Penyusunan Rencana Pengembangan Tanaman Padi \& Palawija di Kabupaten Banyuasin Tahun 2010.

Jumberi A, Alihamsyah T. 2006. Usaha Agribisnis di Lahan Rawa Pasang Surut : Karakteristik dan Pengelolaan Lahan Rawa (Ed : Irsal Las). Balai Besar Penelitian dan Pengembangan Sumberdaya Lahan Pertanian, Badan Penelitian dan Pengembangan Pertanian, Departemen Pertanian.

Subagyo H. 2006a. Klasifikasi dan Penyebaran Lahan Rawa : Karakteristik dan Pengelolaan Lahan Rawa (Ed : Irsal Las). Balai Besar Penelitian dan Pengembangan Sumberdaya Lahan Pertanian, Badan Penelitian dan Pengembangan Pertanian, Departemen Pertanian.

Subagyo H. 2006b. Lahan Rawa Pasang Surut : Karakteristik dan Pengelolaan Lahan Rawa (Ed : Irsal Las). Balai Besar Penelitian dan Pengembangan Sumberdaya Lahan Pertanian, Badan Penelitian dan Pengembangan Pertanian, Departemen Pertanian.

Umboh AH. 1996. Karakter fisiologi pertumbuhan pembeda tingkat toleransi beberapa klon ubi jalar (Ipomoea batatas (L). Lam) terhadap salinitas. Program Pascasarjana, IPB. Thesis. 